\title{
PERANCANGAN APLIKASI SISTEM INFORMASI PENYEWAAN KASET (CD) PADA RENTAL KASET AKIN TANJUNG PENDAM
}

\author{
Melati Suci Mayasari \\ Program Studi Manajemen Informatika \\ STMIK Atma Luhur \\ Email: imeal_melati@atmaluhur.ac.id
}

\begin{abstract}
ABSTRAK
Tujuan penelitian ini adalah menghasilkan sistem informasi penyewaan kaset secara komputerisasi dimana sistem penyewaan kaset sebelumnya masih menggunakan sistem manual, sehingga lebih efisien dan optimal guna mendukung kemajuan dan perkembangan rental tersebut. Dengan memanfaatkan sistem informasi penyewaan kaset yang sudah terkomputerisasi ini dapat memberikan kemudahan dalam pelayanan dan penyajian informasi, meningkatkan kinerja serta pengolahan data yang lebih baik, tepat, cepat dan akurat. Peningkatan kinerja kerja tidak terlepas dari sarana dan prasarana, salah satunya adalah dukungan teknologi dan sistem informasi yang sesuai dengan kebutuhan. Dimana data dapat diproses dan diolah sehingga menghasilkan suatu informasi guna mendukung keputusan yang baik. Persaingan yang semakin ketat akibat perkembangan pesat bidang teknologi serta pergeseran demografi dan kondisi ekonomi yang tidak menentu juga dapat memicu perubahan di lingkungan bisnis ke arah ketidakpastian dan kompleks. Daya saing sebagai dasar keunggulan ditentukan oleh kemampuan berkembang dan memahami perubahan perilaku atau organisasi (sistem) yang melibatkan kombinasi pemikiran, proses serta pemenafaatan secara efektif teknologi dan manusia guna menghasilkan sesuatu yang berbeda atau lebih baik. Sistem Informasi Penyewaan Kaset (CD) pada Rental Kaset Akin Tanjung Pendam Kabupaten Belitung ini merupakan sistem informasi penyewaan kaset yang dirancang dengan menggunakan metodologi berorientasi objek dengan alat bantu UML (Unified Modelling Language), pengamatan langsung dan wawancara dengan pihak yang terkait.
\end{abstract}

Kata kunci: penyewaan, teknologi, aplikasi, sistem informasi, $U M L$, metodologi berorientasi objek

\begin{abstract}
Work performance improvement can't be separated from its infrastructure especially technology and information supportsystems in accordance with the requirements. Where data can be processed to produce an information for better decision. Competition increase due to technologys rapid development as well as demographic shifts and uncertain economic conditions affected business environment that become uncertainty and complex. Competitiveness as the foundation of excellence is determined by the ability to grow and understand changes in behavior or system which is involves a combination of ideas, processes and technology effectively in order to produce something different or better. CassetteRental Information Systems on Rental Kaset Akin Tanjung Pendam Kabupaten Belitung is an information system designed using object oriented methodology with UML (Unified Modeling Language)tools, direct observation and interviews with stakeholders. The purpose of this research is to produce a cassetterental information system that is more efficient and optimized to support the progress and development of the rental. By usingthiscassette rental information systems that are already computerized can provide ease of service and presentation of information, improve performance and better data processing, precise, fast and accurate.
\end{abstract}

Keywords: rentals, technology, applications, information systesm, UML, object oriented methodology

\section{PENDAHULUAN}

Seiring dengan perkembangan teknologi dan informasi yang semakin cepat menuntut untuk segera dilakukan perubahan yang cukup besar. Kemajuan teknologi merupakan faktor yang sangat penting, tanpa adanya teknologi yang mendukung maka persaingan antar perusahaan terhambat. Perusahaan dituntut untuk bekerja secara ekonomis, efektif, dan efisien agar dapat bergerak mengikuti perkembangan ekonomi yang makin berkembang tersebut.

Dalam sebuah perusahaan yang sebagiannya belum menggunakan komputer, hampir sebagian pekerjaan dilakukan secara manual. Jumlah pegawai dan jam kerjanya dalam melakukan pelayanan terhadap konsumen, akan terus berkembang sesuai dengan makin banyaknya beban kerja untuk pengolahan data. Saat ini penggunaan komputer terbanyak adalah dunia bisnis/usaha dimana proses 
umumnya tidak terlalu rumit namun menyangkut data/informasi yang sangat banyak dengan ragam jenis yang sangat banyak. Kebutuhan akan informasi dimasa datang akan menduduki posisi penting dan urutan yang utama di berbagai bidang tanpa melihat latar belakang kehidupan seseorang.

Masalah yang sering terjadi dalam transaksi penyewaan kaset pada rental kaset akin ini adalah masih dilakukan secara manual, sehingga dengan keadaan tersebut kadang-kadang menimbulkan kesalahan terutama dalam proses penyewaan, pengembalian kaset, penyimpanan dan pencarian data konsumen, serta pembuatan laporan yang belum lengkap dan akurat.

Berdasarkan permasalahan yang ada saat ini, penulis ingin mencari solusi dengan membuat perancangan sistem informasi penyewaan kaset yang terkomputerisasi agar sistem dapat dilaksanakan dengan cepat dan tepat waktu. Serta diharapkan dapat memudahkan mengontrol data masukan dan keluaran sehingga informasi yang dibutuhkan jadi lebih cepat dan akurat untuk menghasilkan sistem yang lebih optimal dan efisien, serta meningkatkan kualitas kinerja dan pelayanan terhadap konsumen.

Sistem Informasi berasal dari kata Sistem dan Informasi. Sistem adalah satu jaringan kerja dalam suatu prosedur yang paling berhubungan satu sama lain dengan maksud yang sama. "Informasi adalah data yang telah diproses yang memiliki arti."[1]. Sedangkan menurut Wahyono Teguh, sistem adalah "Suatu kesatuan utuh yang terdiri dari beberapa bagian yang saling berhubungan dan berinteraksi untuk mencapai tujuan tertentu.’[2]. Adapun syarat-syarat sistem adalah sebagai berikut :

a. Sistem harus dibentuk untuk menyelesaikan masalah.

b. Elemen sistem harus mempunyai rencana yang ditetapkan.

c. Adanya hubungan diantara elemen sistem.

d. Unsur dasar dari proses (arus informasi, energi dan material) lebih penting dari pada elemen sistem.

e. Tujuan organisasi lebih penting dari pada tujuan elemen.

Dari definisi diatas dapat disimpulkan bahwa infomasi adalah data yang diolah menjadi bentuk yang lebih berarti bagi penerimanya dan bermanfaat dalam mengambil keputusan. Istilah informasi mengarah pada penggunaan teknologi komputer didalam organisasi untuk menyajikan infomasi kepada pemakai. Informasi juga merupakan hal yang sangat penting bagi manajemen didalam pengambilan keputusan. Sistem Infomasi adalah "Sebagai satuan yang saling berhubungan yang mengumpulkan (mendapatkan komponen kembali), memproses, menyimpan dan mendistribusikan informasi untuk mendukung pengambilan keputusan dan kendali dalam suatu organisasi.’[3]

Konsep dasar berorientasi objek mencapai puncaknya pada saat masalah analisis dan desain menjadi lebih diperhatikan dari pada masalah coding. Analisa dan perancangan sistem berorientasi objek merupakan cara baru untuk menggambarkan suatu masalah dengan menggunakan model yang dibuat menurut konsep sekitar dunia nyata. Dalam hal ini dasar pembuatannya adalah objek, dimana objek tersebut merupakan kombinasi antara struktur data dan perilaku dalam suatu entitas. " Berorientasi Objek adalah kita mengorganisasikan perangkat lunak sebagai kumpulan dari objek tertentu yang memiliki struktur data dan perilaku."'[4] Tools yang digunakan untuk menggambarkan objek-objek tersebut adalah UML (Unified Modelling Language). UML adalah "bahasa" yang telah menjadi standar dalam industri untuk visualisasi, merancang dan mendokumentasikan sistem perangkat lunak. Adapun tujuan utama $U M L$ antara lain untuk :

a. Memberikan model yang siap pakai, bahasa visual yang ekspresif untuk mengembangkan dan saling menukar model dengan mudah dan dimengerti secara umum.

b. Memberikan bahasa pemodelan yang bebas dari berbagai bahasa pemrograman dan proses rekayasa.

c. Menyatukan praktek-praktek terbaik yang terdapat dalam pemodelan.

Untuk membuat suatu model, $U M L$ mendefinisikan diagram-diagram berikut ini :
a. Usecase Diagram
f. Interaction Diagram
b. Class Diagram
g. Sequence Diagram
c. Behavior Diagram
d. Statechart Diagram
h. Colaboration Diagram
e. Activity Diagram
i. Component Diagram
j. Deployment Diagram

\section{METODOLOGI PENELITIAN}

Metodologi Penelitian yang digunakan dalam mengumpulkan informasi dan data-data yang diperlukan dalam penelitian ini adalah sebagai berikut :

a. Observasi; Dilakukan untuk mengumpulkan data dengan cara pengamatan langsung. 
b. Wawancara; Mempelajari dan menganalisa sistem yang sedang berjalan serta mendapatkan data langsung dari sumbernya dengan tanya jawab. Dengan wawancara diharapkan informasi yang diperoleh benar-benar dapat dipertanggung jawabkan sesuai dengan pertanyaan yang diajukan.

c. Studi Kepustakaan; Dilakukan dengan cara membaca buku-buku yang berkaitan dengan masalah penyewaan atau rental.

d. Analisa Sistem

Menceritakan proses bisnis atau alur kerja sebuah proses bisnis dan urutan aktivitas didalam proses penyewaan kaset dan menggunakan usecase diagram untuk menganalisa kebutuhan sistem dari sudut pandang user.

e. Perancangan Sistem dengan menggunakan Entity Relationship Diagram, Transformasi ERD ke LRS, LRS, Tabel, dan Rancangan Layar.

\section{HASIL PENELITIAN DAN PEMBAHASAN}

\subsection{Proses Bisnis Sistem Berjalan}

Adapun proses bisnis sistem yang berjalan adalah sebagai berikut :

a. Proses Pendataan pelanggan

Setiap ada pelanggan yang ingin menyewa kaset, pegawai akan meminta kartu identitas penyewa terlebih dahulu seperti Kartu TandaPenduduk (KTP) atau kartu identitas lainnya. Data-data yang diperlukan akan dicatat ke dalam buku penyewaan.

b. Proses Penyewaan Kaset

Pelanggan menyerahkan kaset-kaset yang mau disewa kepada pegawai. Kemudian pegawai akan mencatat kaset-kaset yang mau disewa ke dalam buku penyewaan. Kemudian pegawai toko menkonfirmasi total pembayaran yang harus dibayar oleh pelanggan dan mencatatnya ke dalam buku penyewaan. Total pembayaran didapat dari jumlah keping CD yang ia sewa dikalikan Rp 2.500 ditambah uang jaminan sebesar Rp 10.000. Setelah melakukan pembayaran, pegawai akan memberikan nota penyewaan kepada pelanggan.

c. Proses Pengembalian Kaset

Penyewa memberikan kaset yang akan dikembalikan kepada pegawai. Berdasarkan buku penyewaan kaset, pegawai mengecek apakah penyewa tersebut terlambat mengembalikan kaset atau tidak. Apabila terlambat, maka pegawai akan mengkonfirmasikan kepada pelanggan bahwa ia harus membayar denda keterlambatan sebesar 5000 per hari. Apabila tidak terlambat, pegawai akan mencatat ke dalam buku penyewaan kaset. Kemudian pegawai akan mengecek kondisi keping CD, apabila ada kerusakan seperti patah atau tergores, maka pegawai akan mengkonfirmasi kepada pelanggan bahwa uang jaminannya tidak akan dipotong karena harus mengganti rugi atas kerusakan keping CD. Apabila tidak ada kerusakan maka uang jaminan pelanggan akan dikembalikan.

d. Proses Pembuatan Laporan Bulanan

Setiap bulannya, pegawai membuat laporan bulanan yang berisi daftar kaset yang disewa dan pendapatan perbulan. Laporan tersebut diberikan kepada pemilik toko.

\subsection{Analisa Dokumen Keluaran Sistem Berjalan}

Berikut ini adalah analisa dokumen keluaran pada sistem berjalan yang ada pada sistem penyewaan kaset di Rental Kaset Akin :

a. Nama Keluaran : Nota Penyewaan

Fungsi : Sebagai bukti penyewaan kaset

Media : Kertas

Distribusi : Pelanggan

Rangkap : 1 (satu)

Frekuensi : Setiap adanya transaksi penyewaan kaset

Volume : 10/hari

Keterangan : Berisi tentang transaksi penyewaan seperti tanggal sewa, daftar kaset yang disewa, jumlahpembayaran, tanggal harus mengembalikan kaset.

Hasil Analisa : Informasi yang diberikan cukup jelas.

b. Nama Keluaran : Laporan Bulanan

Fungsi : Untuk melaporkan data penyewaan selama satu bulan

Media : : Buku

Distribusi : Pemilik toko 


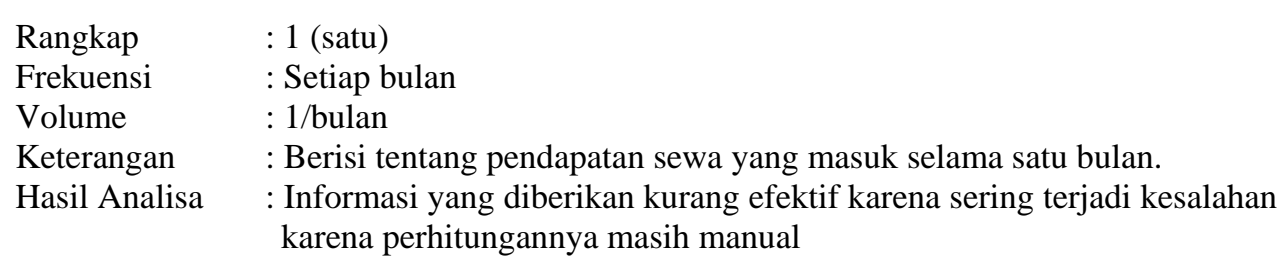

\subsection{Analisa Dokumen Masukan Sistem Berjalan}

Berikut adalah analisa dokumen masukan pada sistem berjalan yang ada pada sistem penyewaan kaset di Rental Kaset Akin :

a. Nama Masukan : Data pelanggan

Sumber : Pelanggan

Fungsi : Sebagai informasi identitas pelanggan

Media : : Buku

Rangkap $\quad: 1$ (satu)

Frekuensi : Setiap ada penyewa yang mau menyewa kaset

Volume : : 10/hari

Keterangan : Memuat informasi mengenai data diri pelanggan berdasarkan kartu identitas yang dimiliki oleh pelanggan.

Hasil Analisa : Struktur data sangat berantakan dan tidak rapi karena masih menggunakan buku, juga terdapat data yang bersifat ganda.

b. Nama Masukan : Data kaset

Sumber : Pemilik Toko

Fungsi : Sebagai informasi data-data kaset

Media : Buku

Rangkap : 1 (satu)

Frekuensi : Setiap ada pemasukan data kaset.

Volume : 1/minggu

Keterangan : Memuat informasi mengenai data-data kaset.

Hasil Analisa : Struktur data sangat berantakan dan tidak rapi karena masih menggunakan buku, juga terdapat data yang bersifat ganda.

c. Nama Masukan : Data Penyewaan Kaset

Sumber : Pelanggan

Fungsi $\quad$ : Sebagai informasi mengenai daftar kaset yang disewa pelanggan

Media : Buku

Rangkap $\quad: 1$ (satu)

Frekuensi : Setiap ada transaksi penyewaan

Volume $\quad:$ 10/hari

Keterangan : Memuat informasi mengenai daftar kaset-kaset yang disewa oleh pelanggan.

Hasil Analisa : Data sangat berantakan dan menjadi tidak terstruktur karena digabung dengan data pelanggan.

d. Nama Masukan : Data pengembalian kaset

Sumber : Pelanggan

Fungsi : Sebagai Informasi mengenai pengembalian kaset oleh pelanggan

Media : Buku

Rangkap : 1 (satu)

Frekuensi : Setiap ada transaksi pengembalian

Volume : 10/hari

Keterangan : Memuat informasi mengenai data pengembalian kaset oleh pelanggan.

Hasil Analisa : Informasi cukup jelas

e. Nama Masukan : Data denda

Sumber : Pelanggan

Fungsi : Sebagai informasi denda yang terjadi akibat keterlambatan pelanggan

Media $\quad$ : Buku

Rangkap : 1 (satu)

Frekuensi : Setiap ada pelanggan yang terlambat mengembalikan kaset.

Volume : 2/hari 
Keterangan : Memuat informasi mengenai data-data denda.

Hasil Analisa : Informasi yang dihasilkan cukup baik.

\subsection{UseCase Diagram Sistem Usulan}

Use case diagram digunakan untuk menggambarkan kebutuhan dan fungsionalitas sistem dari sudut pandang user berdasarkan hasil analisa yang telah dilakukan yang terfokus pada sistem yang terkomputerisasi. Adapun usecase diagram sistem tersebut adalah sebagai berikut :

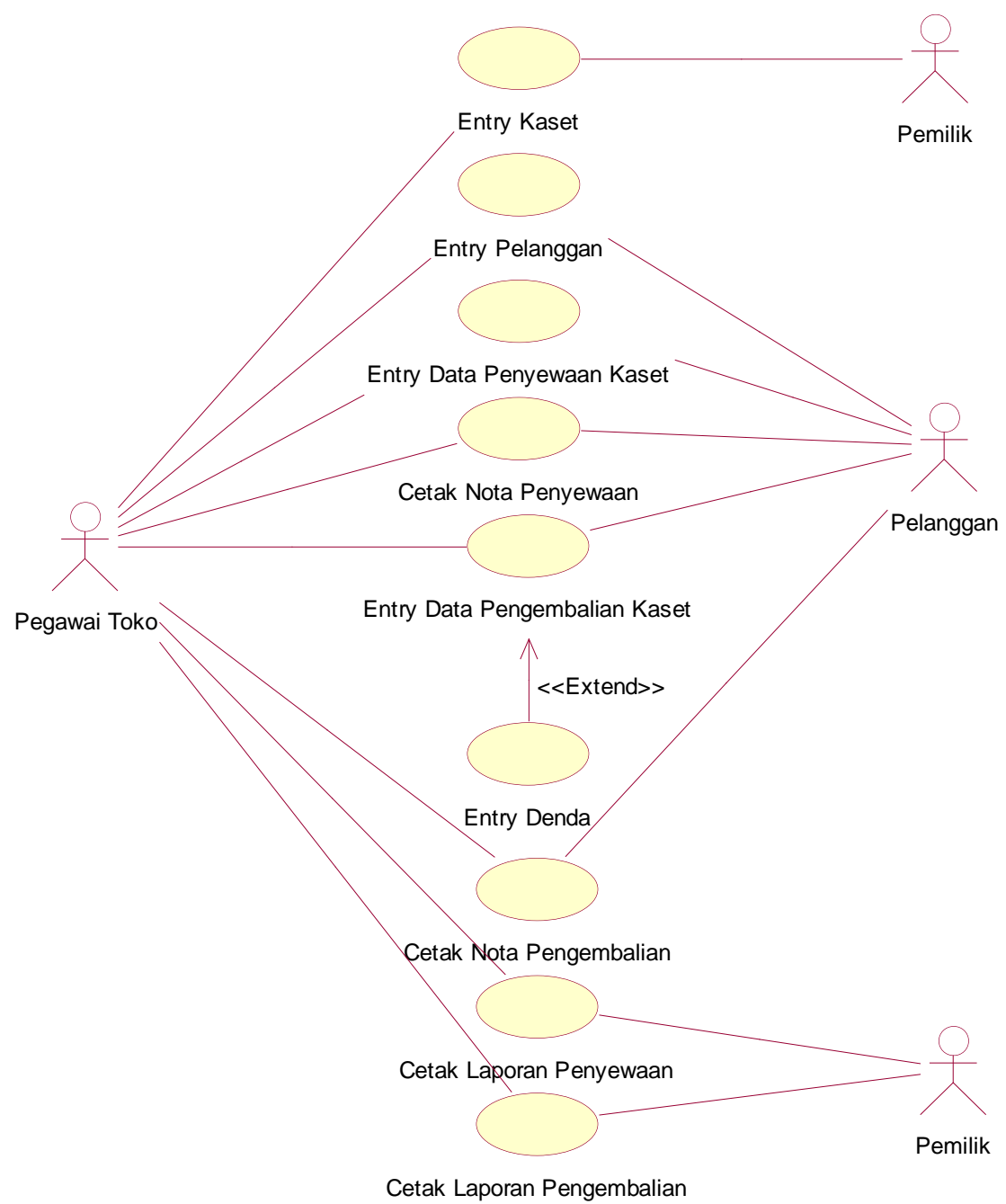

Gambar 1. UseCase Diagram Sistem Usulan

\subsection{Rancangan Basis Data}

\subsubsection{Entity Relationship Diagram (ERD)}

Alat bantu yang digunakan dalam perancangan basis data adalah Entity Relationship Diagram (ERD) yaitu untuk menggambarkan entitas-entitas apa saja yang terlibat dalam sistem informasi penyewaan kaset pada Rental Kaset Akin, yang terlihat pada gambar 2. 


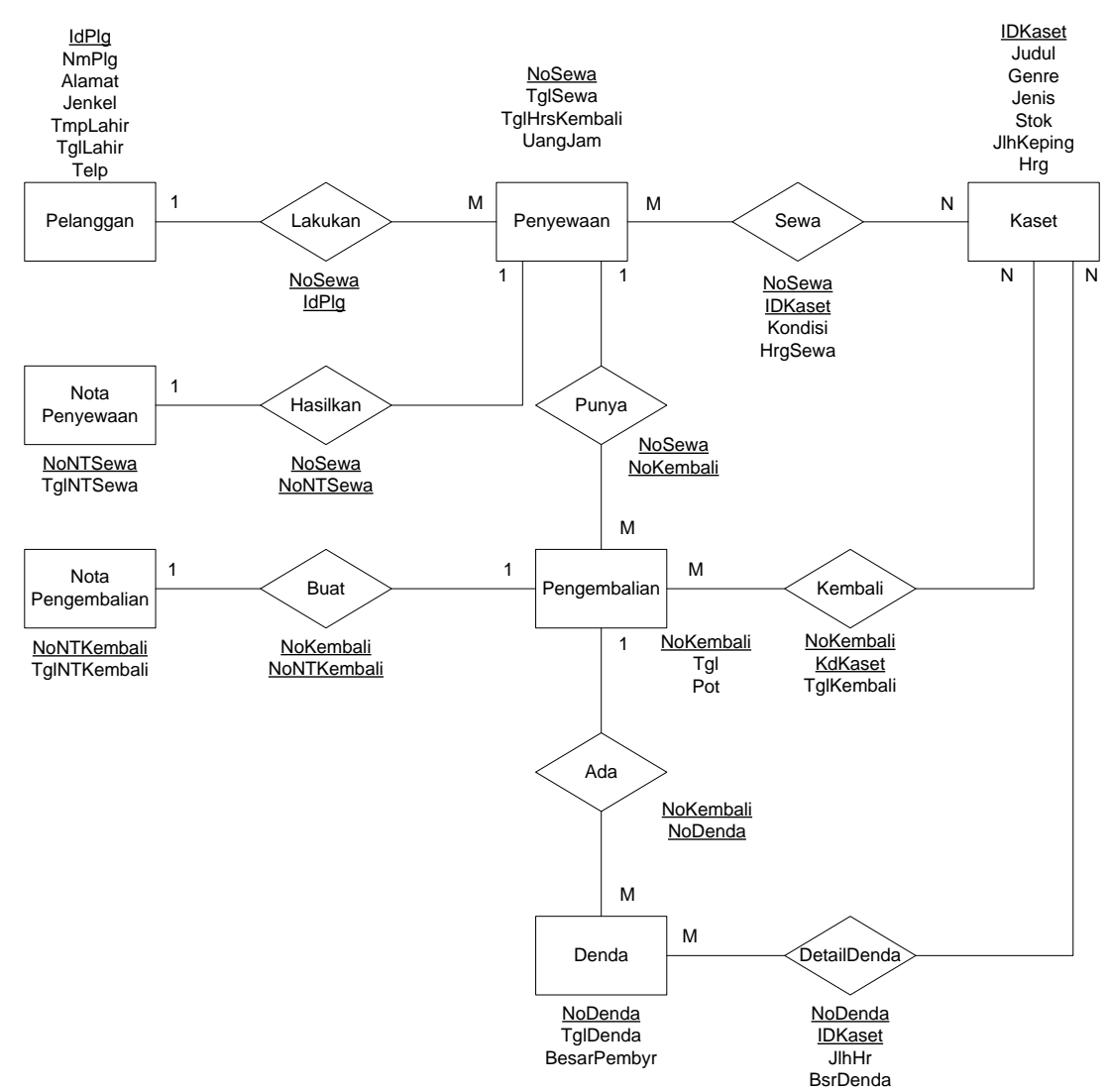

Gambar 2. Entity Relationship Diagram (ERD)

\subsubsection{Transformasi ERD ke LRS}

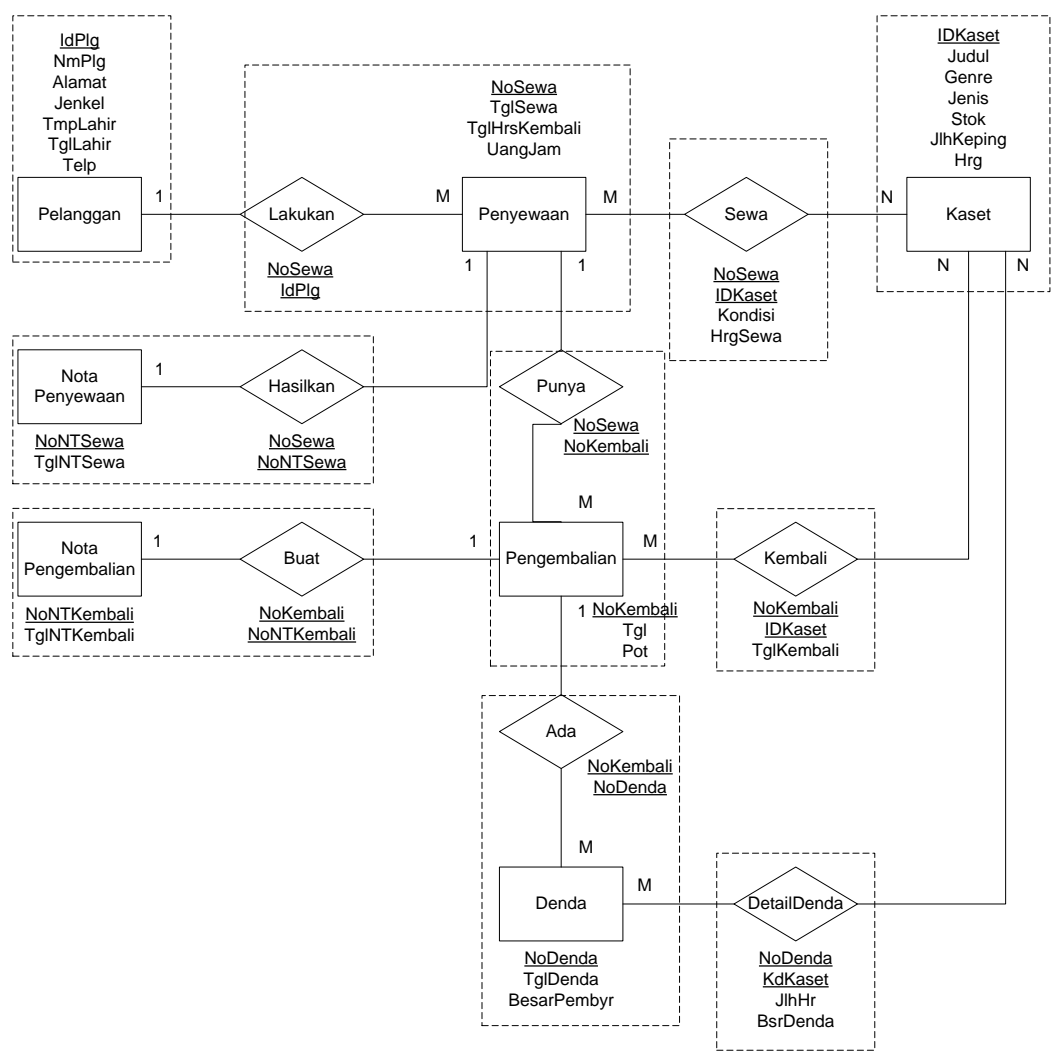

Gambar 3. Transformasi ERD Ke LRS 
3.5.3 Logical Record Structure (LRS)

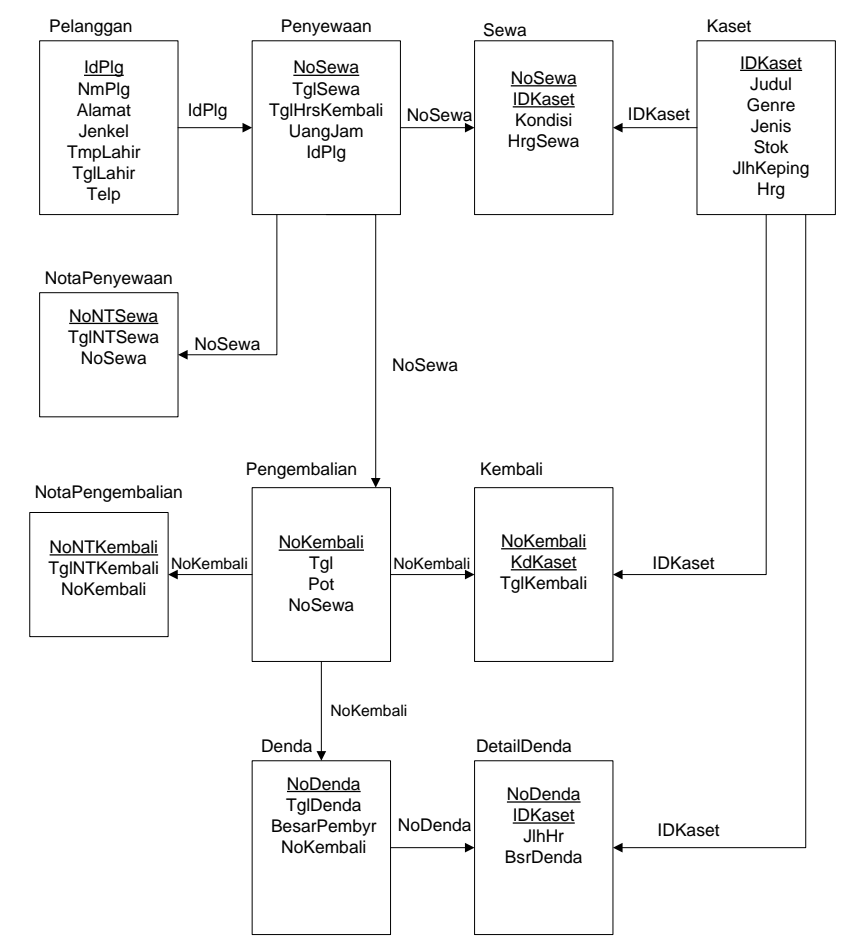

Gambar 4. Logical Record Structure (LRS)

3.6 Rancangan Layar

Adapun beberapa contoh rancangan layar yang dirancang pada sistem ini adalah sebagai berikut :

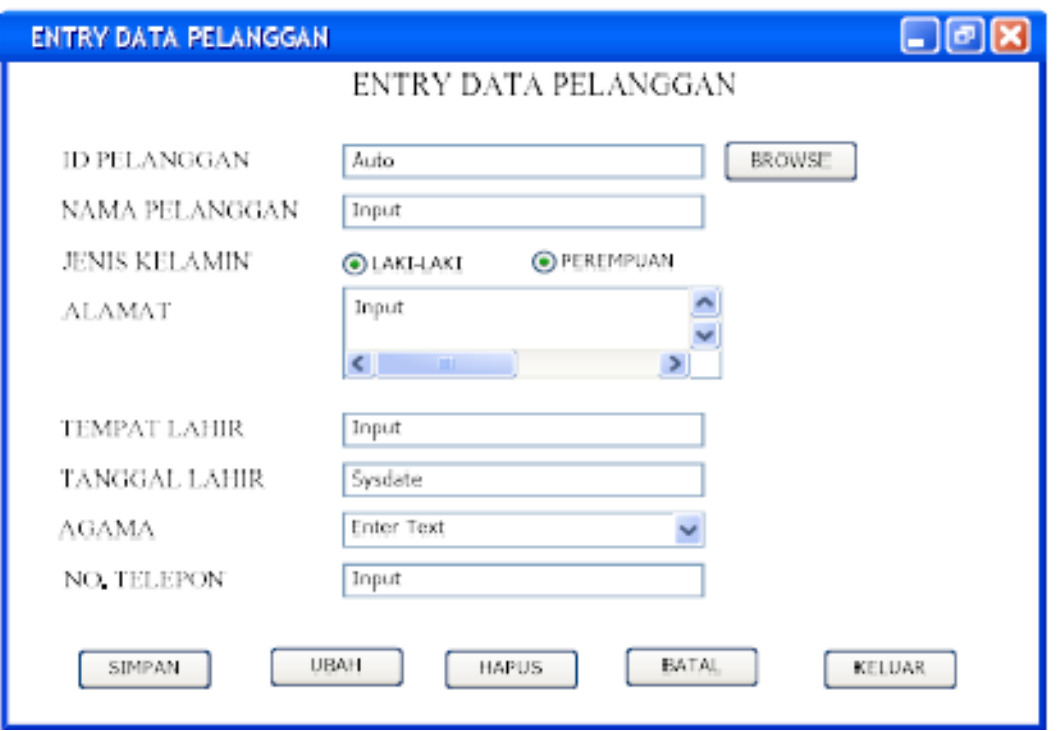

Gambar 5. Rancangan Layar Entry Data Pelanggan 


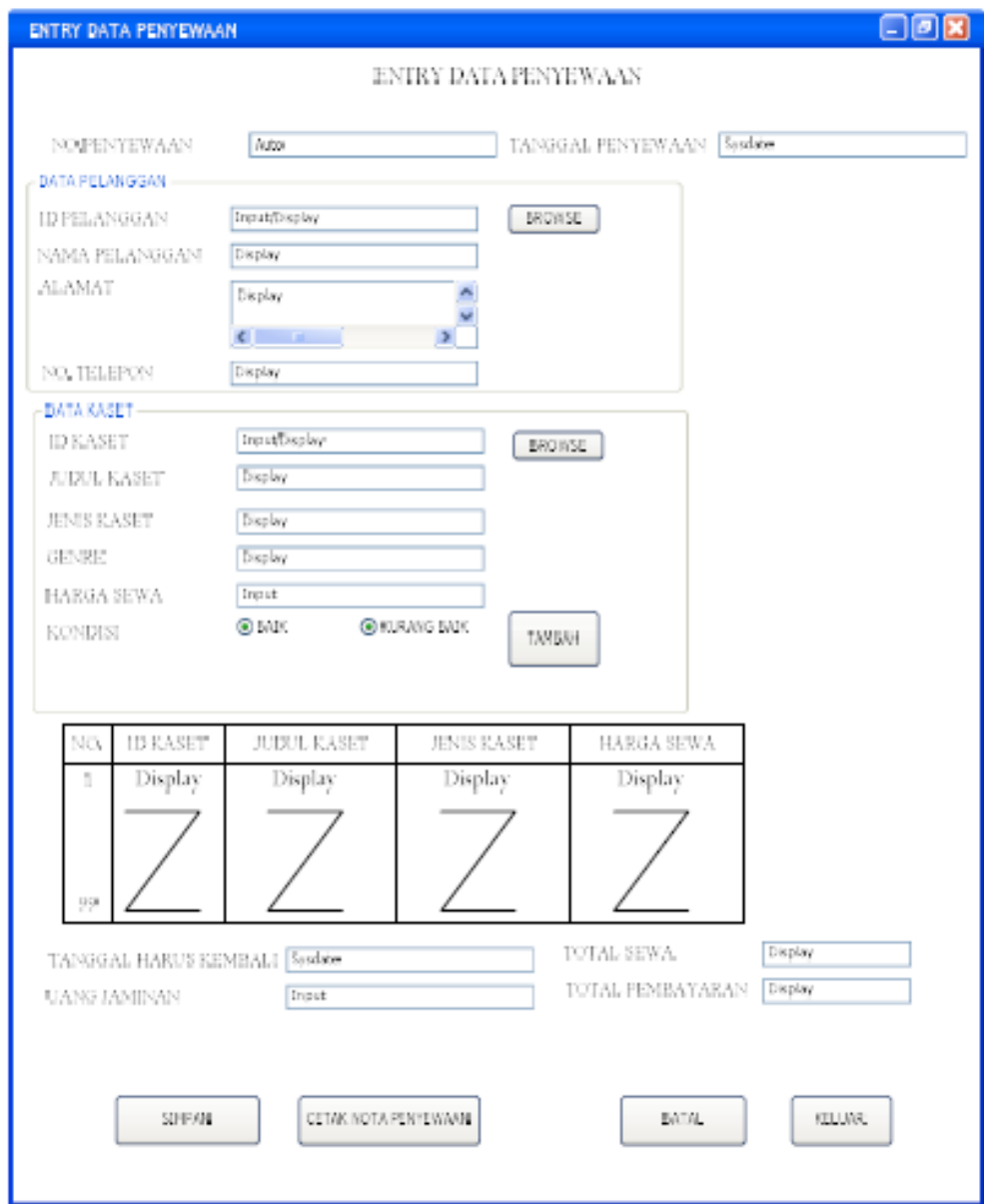

Gambar 6. Rancangan Layar Entry Data Penyewaan

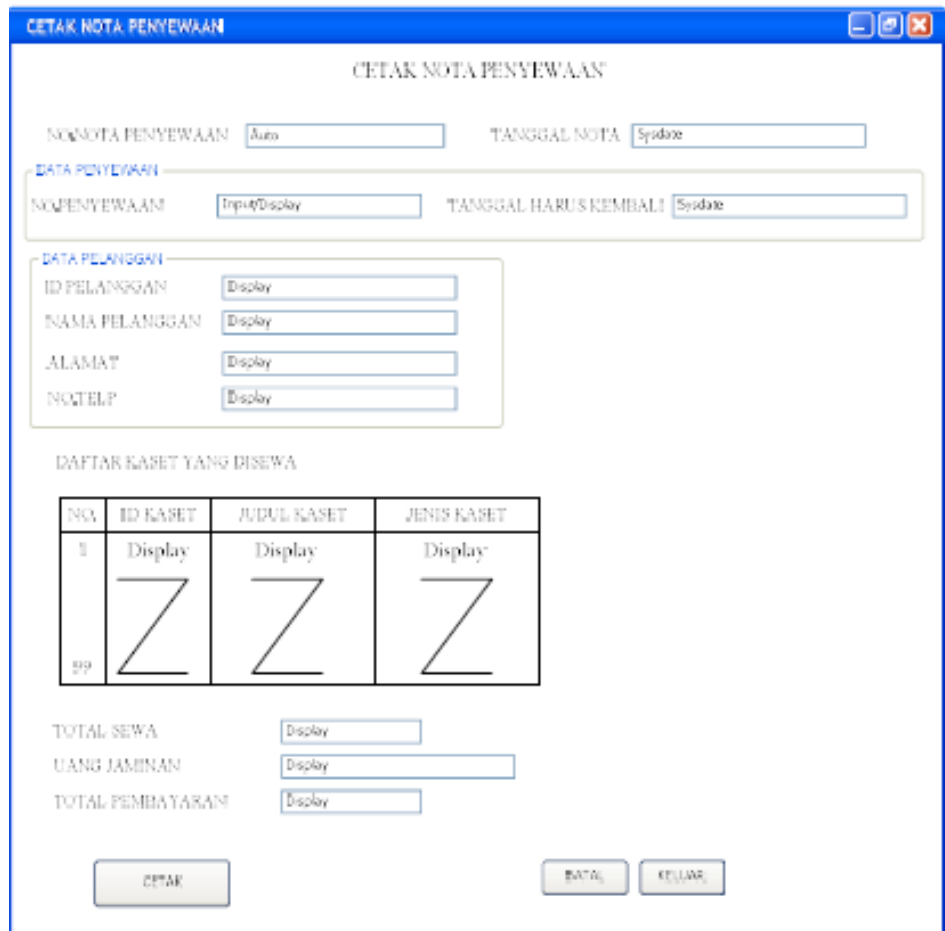

Gambar 7. Rancangan Layar Cetak Nota Penyewaaan 


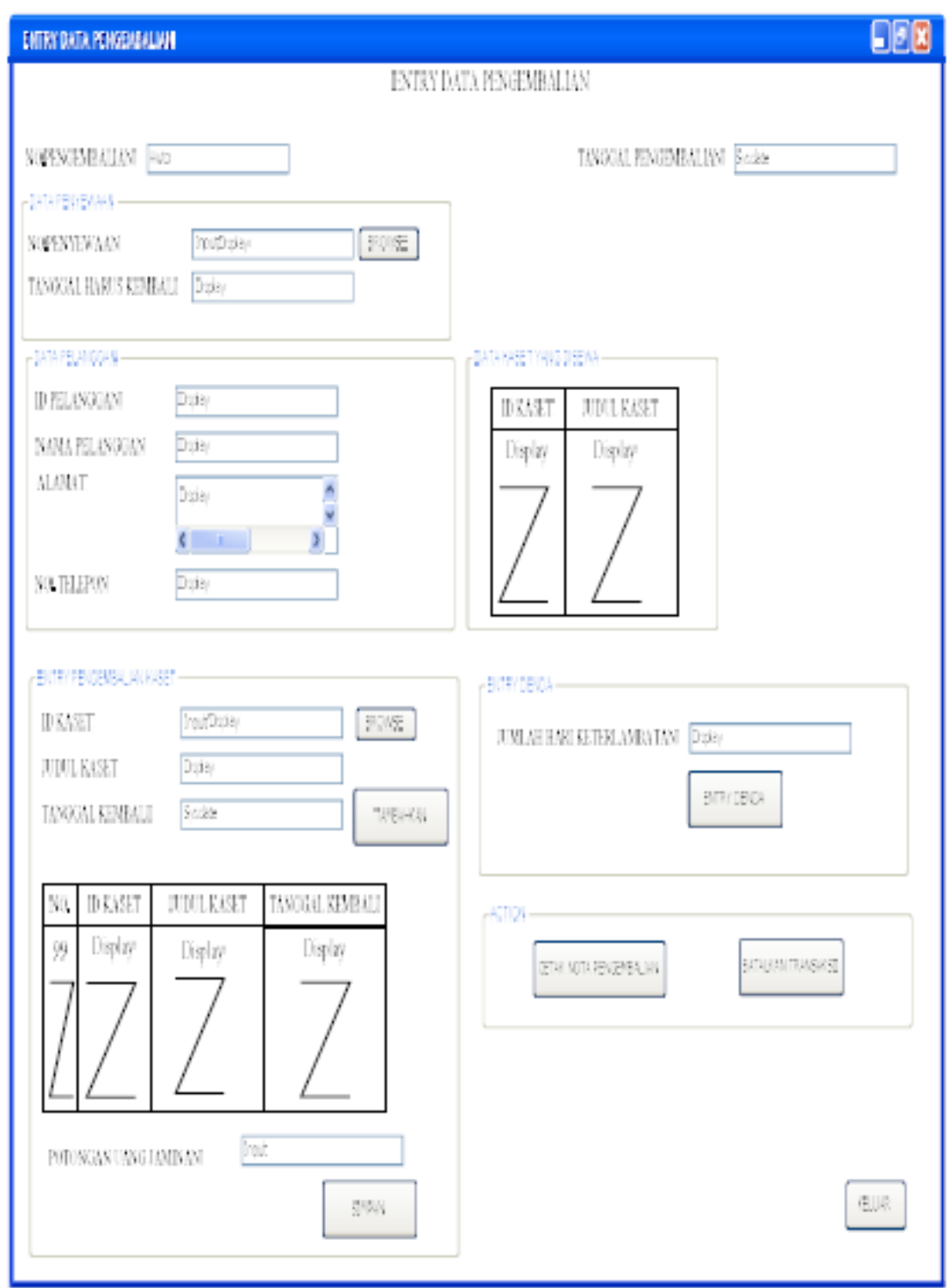

Gambar 8. Rancangan Layar Entry Data Pengembalian

\section{KESIMPULAN}

Dari pembahasan yang sudah diuraikan sebelumnya, disini peneliti akan mencoba untuk menarik beberapa kesimpulan yaitu sebagai berikut :

a. Sangat banyak sekali perbedaan antara sistem informasi penyewaan yang masih menggunakan sistem manual dengan sistem yang sudah terkomputerisasi.

b. Sistem informasi penyewaan kaset yang sudah menggunakan sistem komputerisasi bisa membuat tugas kerja para karyawan toko menjadi lebih mudah dan efisien dibandingkan dengan sistem yang masih menggunakan sistem manual

c. Sistem informasi penyewaan kaset yang sudah terkomputerisasi membuat waktu pelayanan terhadap pelanggan menjadi lebih cepat, sehingga pelanggan merasa nyaman dengan pelayanan yang diberikan oleh karyawan toko.

d. Sistem komputerisasi ini membuat data-data yang diperlukan seperti data kaset, data pelanggan, data penyewaan kaset, data pengembalian kaset dan data denda menjadi lebih terstruktur dan lebih baik.

e. Perhitungan yang dibutuhkan seperti perhitungan total sewa, uang jaminan, total denda menjadi lebih akurat karena dihitung secara otomatis oleh sistem. 
f. Sistem komputerisasi sangat mendukung proses kerja seperti penyimpanan data-data sehingga dapat dengan mudah memberikan informasi yang dibutuhkan pada saat data-data tersebut diperlukan.

g. Dalam rancangan sistem ini, karyawan toko dapat dengan cepat membuat laporan-laporan yang dibutuhkan untuk diberikan kepada pimpinan took setiap bulannya, sehingga perkembangan toko dapat diketahui dengan cepat dan juga bisa membantu pimpinan toko dalam pengambilan keputusan.

h. Penerapan metode berorientasi obyek ini diharapkan dapat memudahkan dalam hal pengembangan sistem yang dirancang.

Adapun saran-saran penulis untuk penelitian lanjutan yaitu :

a. Penelitian selanjutnya dapat dikembangkan pada bidang lain selain penyewaan kaset.

b. Penelitan selanjutnya dapat membangun sistem dengan berbasis web atau online sehingga dapat di akses dimana saja dan kapan saja menggunakan internet.

\section{DAFTAR PUSTAKA}

[1] Kadir, Abdul. (2003). Pengenalan Sistem Informasi. Edisi Pertama. Yogyakarta: ANDI.

[2] Teguh, Wahyono. (2004). Sistem Informasi : Konsep Dasar, Analisis Desain dan Implementasi. Edisi Pertama. Yogyakarta : Graha Ilmu.

[3] Jogiyanto, HM. (2005). Sistem Teknologi Informasi. Yogyakarta : ANDI.

[4] Sutopo, Ariesto Hadi. (2002). Analisis dan Design Berorientasi Objek. Yogyakarta : J dan J Learning. 